\title{
Plagioclase-hosted melt inclusions as indicators of inhibited rhyolitic melt beneath a mafic volcano: a case study of the Izu-Omuroyama monogenetic volcano, Japan
}

\author{
Risako HatadA ${ }^{*}$, Hidemi IshiBASHI ${ }^{*}$, Yukiko SuwA ${ }^{*}$, Yusuke SuZukI ${ }^{* *}$, \\ Natsumi HOKANISHI $^{* * *}$ and Atsushi YASUDA ${ }^{* * *}$ \\ *Department of Geoscience, Faculty of Science, Shizuoka University, Shizuoka 422-8529, Japan \\ ** Izu-Peninsula Geopark Promotion Councill, Shizuoka 410-2416, Japan \\ ${ }^{* * *}$ Earthquake Research Institute, the University of Tokyo, Tokyo 113-0032, Japan
}

\begin{abstract}
We conducted textural and chemical analyses of melt inclusions and their host plagioclase crystals in the scoria of the Izu-Omuroyama monogenetic volcano, erupted at $\sim 4 \mathrm{ka}$ in the Higashi-Izu monogenetic volcanic field, Japan. The groundmass melt was andesitic with $\sim 59-61 \mathrm{wt} \% \mathrm{SiO}_{2}$, and it contained abundant microphenocrysts of olivine and plagioclase. In contrast, $\sim 59 \%$ of the plagioclase-hosted melt inclusions have rhyolitic compositions with $\sim 70-75 \mathrm{wt} \% \mathrm{SiO}_{2}$. The host plagioclase phenocrysts have cores with An\# of $44.7 \pm 4.2$ [An\# = $100 \mathrm{Ca} /(\mathrm{Ca}+\mathrm{Na})$ in $\mathrm{mol}]$ and rims with $\mathrm{An} \#$ of $68-78$, and the calcic rims have compositions similar to the microphenocrysts. The cores of the host plagioclase phenocrysts have $\mathrm{FeO}^{*}$ and $\mathrm{K}_{2} \mathrm{O}$ contents that are in equilibrium with the rhyolitic melt inclusions. Using the plagioclase-melt geohygrometers and assuming temperatures of $790-850{ }^{\circ} \mathrm{C}$, we estimated the $\mathrm{H}_{2} \mathrm{O}$ contents of the rhyolitic melt inclusions to be $\sim 4.4-10.2 \mathrm{wt} \%$, indicating $\mathrm{H}_{2} \mathrm{O}$-saturation depths of $>4.5 \mathrm{~km}$. Our results suggest that an inhibited reservoir of plagioclasebearing rhyolitic melt existed beneath the monogenetic volcano at the time of the scoria eruption, which was $\sim 800$ years earlier than the first rhyolitic eruption in the volcanic field. Plagioclase content in the silicic reservoir is estimated to be less than $35.8 \%$, suggesting the magma was eruptible. Our results demonstrate the potential usefulness of plagioclase-hosted melt inclusions for indicating the existence of such an inhibited silicic magma.
\end{abstract}

Keywords: Melt inclusion, Plagioclase, Monogenetic volcano, Rhyolite, Izu Peninsula

\section{INTRODUCTION}

Unexpected Plinian eruptions of silicic (dacitic-rhyolitic) magma sometimes occur at a composite volcano or a monogenetic volcanic field where only mafic magmas had erupted previously. One such case is the 1707 eruption of Fuji Volcano, Japan, which saw Plinian eruptions of dacitic magma during the initial stage of the eruption (e.g., Miyaji et al., 2011), whereas most volcanic products of the volcano had been basaltic throughout its 100 ky history (e.g., Takahashi et al., 2003). The only exception at Fuji was one eruption at $\sim 3.3$ ka when andesitic magma erupted (Fujii, 2007; Miyaji, 2007). Another example is found in the Higashi-Izu monogenetic volcanic

doi:10.2465/jmps.190724

H. Ishibashi, ishibashi.hidemi@shizuoka.ac.jp Corresponding author field (HIMVF), Izu Peninsula, Japan, where $\sim 70$ monogenetic volcanoes have erupted over the last $150 \mathrm{kyrs}$ (Koyama et al., 1995). The erupted magmas were mainly mafic until the first Plinian eruption of rhyolitic magma at Kawagodaira Volcano at $\sim 3.2 \mathrm{ka} \mathrm{(Shimada,} \mathrm{2000).} \mathrm{We}$ call such silicic melts 'inhibited silicic melt' (Kaneko et al., 2010), because observations suggest that these silicic melts had already formed, but for some reason were delayed from erupting in the generally mafic volcanoes and volcanic fields. Silicic magmas are hazardous in that they have the potential to erupt explosively and more violently than mafic magma although some Plinian eruptions of mafic magmas are known (for example, the 1707 eruption of Fuji volcano, Japan; e.g., Miyaji et al., 2011, the 122 BC eruption of Etna volcano, Italy; e.g., Sable et al., 2006, Houghton et al., 2004, and the 1886 eruption of Tarawara volcano, New Zealand; e.g., Sable et al., 
2006). Therefore, recognizing inhibited silicic melt beneath mafic volcanoes and volcanic fields is important for hazard mitigation.

Phenocrysts sometimes capture parcels of co-existing melt and enclose them as melt inclusions (MIs) during their growth, and the MIs in phenocrysts may therefore provide information about inhibited melts. The compositions of MIs are relatively unchanged after entrapment, because their host crystals effectively separate the MIs from external processes. An example of an MI study that succeeded in finding an inhibited melt is Kaneko et al. (2010), and these researchers measured the chemical compositions of olivine-hosted MIs in scoria erupted before the 1707 Fuji eruption. They found andesitic MIs whereas the host magmas were all basaltic, and Kaneko et al. (2010) proposed that andesitic magma chambers had been developed beneath Fuji Volcano although the erupted magmas were limited to basaltic compositions. The study demonstrated the potential of MIs for recognizing the presence of an inhibited melt. Olivinehosted MIs cannot be used as an indicator of an inhibited silicic melt because olivine is unstable in such a melt. However, plagioclase is stable in melts with a wide compositional range from basaltic to rhyolitic, and it is commonly found as phenocrysts that contain melt inclusions. Therefore, we had high expectations that plagioclasehosted MIs would provide indicators of inhibited silicic melts beneath mafic volcanoes and volcanic fields.

In this paper, we report on our investigation into the chemical compositions of plagioclase-hosted MIs and the host plagioclase crystals in scoria of the Izu-Omuroyama monogenetic volcano, HIMVF, Japan. Our results show that an inhibited rhyolitic melt existed beneath the volcano approximately 800 years before the first silicic Plinian eruption in the volcanic field $(\sim 3.2 \mathrm{ka}$ at Kawagodaira Volcano), thus demonstrating the potential of MIs and their host plagioclase crystals to be used more widely as indicators of inhibited silicic melts beneath mafic volcanoes and volcanic fields.

\section{SAMPLES AND METHODS}

Izu-Omuroyama Volcano is one of the monogenetic volcanoes of the HIMVF, Izu Peninsula, Japan (Fig. 1). The HIMVF has been active for the last $\sim 150 \mathrm{ka}$ and the latest eruption occurred in 1989 at Teishi Kaikyu Volcano (e.g., Yamamoto et al., 1991). The upper surface of the subducting Pacific Plate is located 130-160 km beneath the HIMVF (e.g., Hasegawa et al., 2009). Only mafic magmas (bulk $\mathrm{SiO}_{2}<59$ wt\%; Suzuki, 2000) had been erupted in the HIMVF until $\sim 3.2 \mathrm{ka}$, when the first rhyolitic eruption occurred at Kawagodaira Volcano (Shima- da, 2000). After the Kawagodaira eruption, several other monogenetic volcanoes erupted silicic magmas (bulk $\mathrm{SiO}_{2}>70$ wt\%; Suzuki, 2000).

The Izu-Omuroyama monogenetic volcano erupted at $\sim 4 \mathrm{ka}$ (Saito et al., 2003) and is located in Ito City, which has a population of $\sim 66000$, near the eastern coast of Izu Peninsula (Fig. 1). During the $\sim 4$ ka eruption, $\sim 455 \times 10^{9} \mathrm{~kg}$ of basaltic andesite was discharged, and the largest pyroclastic cone in the volcanic field was formed (Koyano et al., 1996). According to Koyano et al. (1996), the eruption started with a sub-plinian phase (stage A: $\sim 6 \times 10^{9} \mathrm{~kg}$ ), followed by a weak eruption of volcanic ash (stage B: $\sim 34 \times 10^{9} \mathrm{~kg}$ ). Activity then shifted to a Strombolian stage of eruption (stage C: $\sim 82 \times 10^{9}$ $\mathrm{kg}$ ) with small amounts of lava flow and the formation of the pyroclastic cone $\left(\sim 36 \times 10^{9} \mathrm{~kg}\right)$. Subsequently, the explosive activity weakened but a large amount of lava was effused (stage D: $~ 332 \times 10^{9} \mathrm{~kg}$, which includes $\sim 308 \times 10^{9} \mathrm{~kg}$ of lava). The eruptive activity finished after a small explosion on the southern flank of the scoria cone (stage E: $\sim 0.7 \times 10^{9} \mathrm{~kg}$ ). According to previous petrological studies, the erupted magma has a bulk composition of basaltic andesite with $\mathrm{SiO}_{2} \sim 55.4 \mathrm{wt} \%$ (Suzu$\mathrm{ki}, 2000$ ), and the rocks contain olivine and plagioclase phenocrysts with trace amounts of corroded quartz xenocrysts (Miyajima, 1990). However, the chemical compositions of the plagioclase-hosted MIs and the host plagioclase crystals were not measured.

For our study, we analyzed the textures and measured chemical compositions of the plagioclase-hosted MIs and the host plagioclase crystals in the scoria that was deposited during the stage-C strombolian eruption of the Izu-Omuroyama Volcano. Unfortunately, there is no outcrop where the fall deposits of other stages of the eruption can be collected. We collected the stage-C scoria samples at an outcrop located $\sim 500 \mathrm{~m}$ west of the volcanic center, where Koyano et al. (1996) had described the stratigraphy (spot 25). We mounted 430 grains of scoria (2-4 $\mathrm{mm}$ in size) in epoxy resin and then processed these mounts into polished thin sections for microscopic observation. Of these grains, 110 were used for EMP analysis.

We used an FE-EPMA (JEOL JXA-8530FPlus) at the Earthquake Research Institute (ERI) of the University of Tokyo, Japan, to produce backscatter electron (BSE) images of the scoria samples. In addition, the chemical compositions of the MIs and their host plagioclase crystals were measured by EPMA (JEOL-8800R) at the ERI. For the analyses, the accelerating voltage, analytical current, and beam size conditions were $15 \mathrm{kV}, 12 \mathrm{nA}$, and 10 $\mu \mathrm{m}$, respectively. The $1 \sigma$ relative errors of the element measurements are $<0.7 \mathrm{rel} \%$ for $\mathrm{Si} ;<1 \mathrm{rel} \%$ for $\mathrm{Al}, \mathrm{Fe}$, $\mathrm{Mg}$, and $\mathrm{Ca} ;<5 \mathrm{rel} \%$ for $\mathrm{Ti}$ and $\mathrm{Na} ;<10 \mathrm{rel} \%$ for $\mathrm{K}$; and 


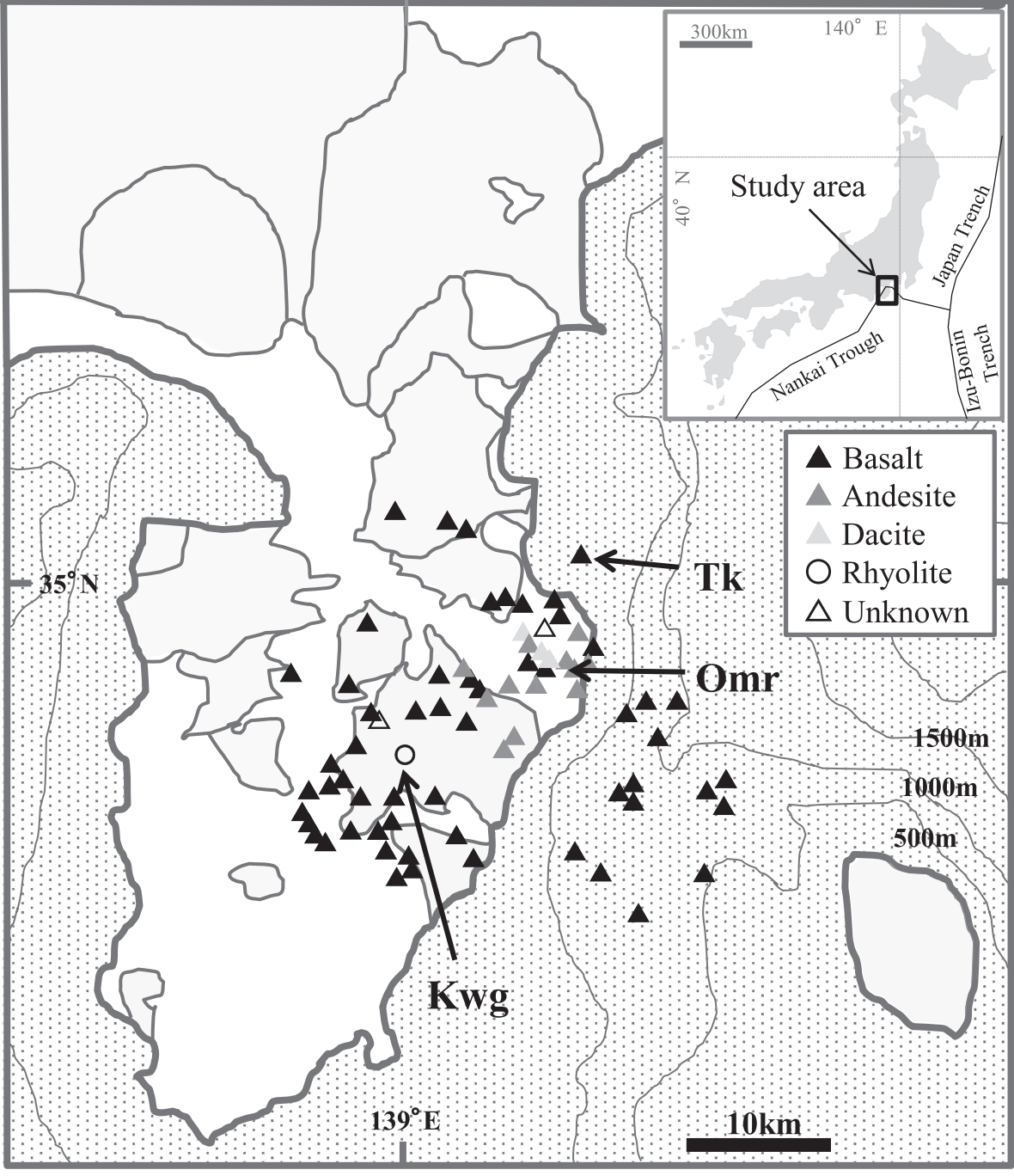

Figure 1. Geological map of the Higashi-Izu monogenetic volcanic field, simplified after Koyama et al. (1995). Symbols indicate the locations of monogenetic volcanoes that are basaltic (black triangles), andesitic (dark gray triangles), dacitic (light gray triangles), rhyolitic (open circle), and unknown (open triangles). Omr, Omuroyama; Kwg, Kawagodaira; Tk, Teishi-Kaikyu. Light gray area shows the distribution of the Quaternary polygenetic volcanoes after Koyama et al. (1995).
$<20 \mathrm{rel} \%$ for Mn (Nagasaki et al., 2017). To investigate the compositional relationships between the MIs and their host plagioclase crystals, we measured 3-4 spots of plagioclase in contact with individual MIs, and the compositions indicated by those analyses were always within analytical uncertainty of each other.

\section{RESULTS AND DISCUSSION}

The scoria contains phenocrysts of plagioclase $(\sim 1.1-5.7$ vol\%), olivine ( $\sim$ 0.4-3.4 vol\%), and trace amounts of quartz $(<1 \mathrm{vol} \%)$ (Fig. 2). The groundmass is made up of microphenocrysts of plagioclase, olivine and pyroxene (typically several tens to $100 \mu \mathrm{m}$ in size) that are embedded either in a microlite-poor andesitic glass or in a mixture of glass and microlites. The microlites are made of plagioclase and pyroxene that are typically $<$ several tens of microns in size (Figs. 2a and 2b). The olivine phenocrysts are euhedral-subhedral and chemically almost ho- mogeneous within each grain with normally zoned outermost rim less than several tens of microns in thickness (Fig. 2c). Olivine phenocrysts with reverse zoning are also found occasionally. The olivine phenocrysts commonly contain MIs and spinel inclusions. Quartz crystals appear to have been partially corroded and surrounded by reaction rims of pyroxene (Fig. $2 \mathrm{~d}$ ).

The plagioclase phenocrysts typically have low$\mathrm{An} \#[\mathrm{An} \#=100 \mathrm{Ca} /(\mathrm{Ca}+\mathrm{Na})$ in $\mathrm{mol}]$ in their cores, and higher contents of An in dusty zones around the cores (Fig. 2e). The gray-scale level of the outermost rims of the plagioclase phenocrysts is similar to that of the plagioclase microphenocrysts in the groundmass, indicating similar contents of An. The plagioclase cores are typically clear and homogeneous or show weak oscillatory zoning (Fig. 2e), but textures suggesting corrosion are sometimes found (Fig. 2f). MIs occur in both the cores and the dusty zones of the plagioclase phenocrysts, although those in the dusty zones are too fine for EMP 

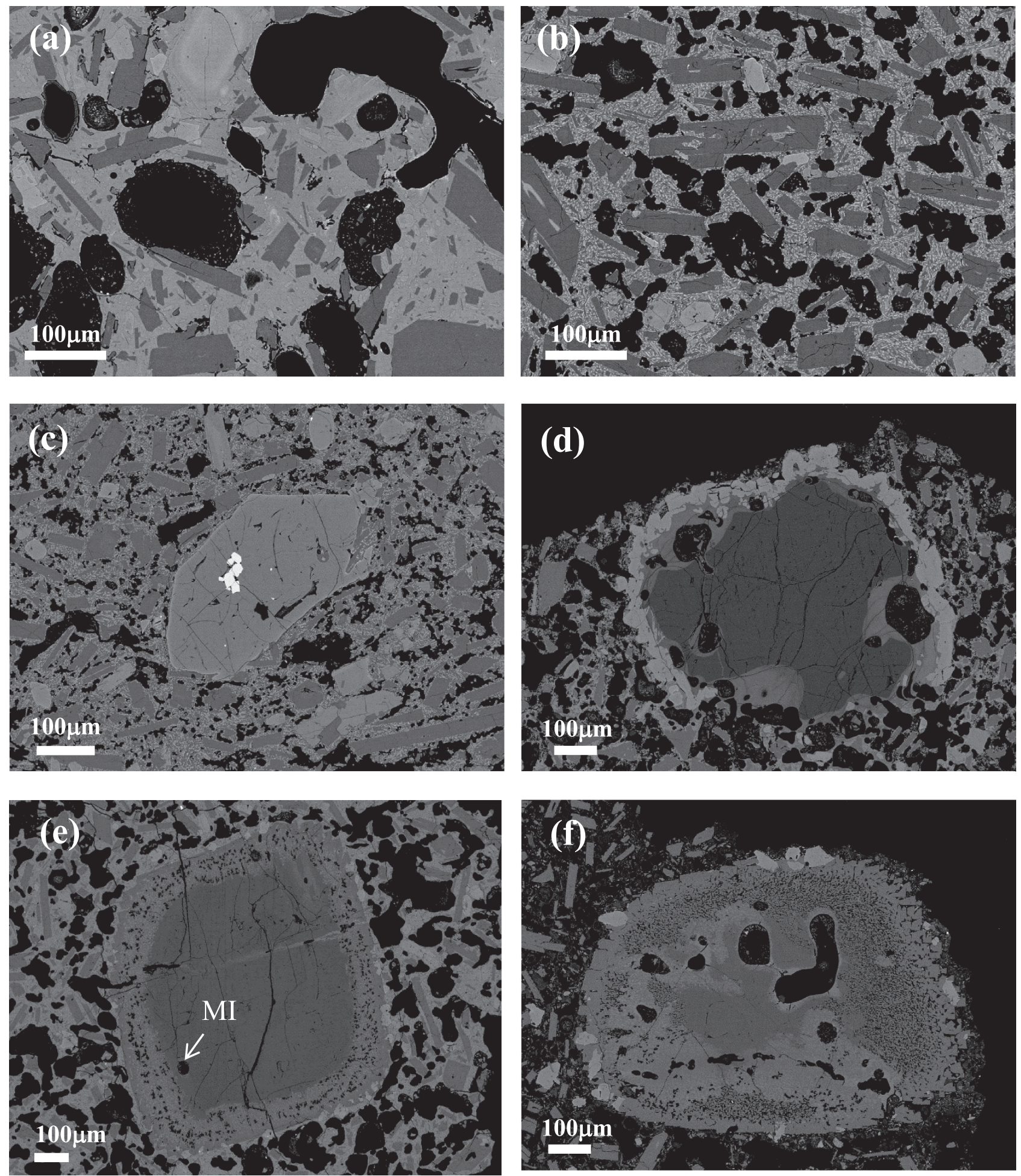

Figure 2. BSE images of the scoria: (a) glassy groundmass. (b) Microlite-rich groundmass. (c) An olivine phenocryst. White inclusions are Cr-spinel. (d) A quartz crystal surrounded by a pyroxene rim. (e) A plagioclase phenocryst with a relatively An-poor core surrounded by a dusty zone and a relatively An-rich rim. The arrow indicates a melt inclusion. (f) A plagioclase phenocryst with partially corroded core. Dark gray rectangles in these figures are plagioclase microphenocrysts.

analyses (Fig. 2e).

Among the 110 scoria grains observed by $\mathrm{FE}-$ EPMA, 49 contain 56 plagioclase phenocrysts. We inves- tigated those phenocrysts and found 29 of them hosted MIs large enough for EMP analysis. The major element compositions of the plagioclase-hosted MIs and the 


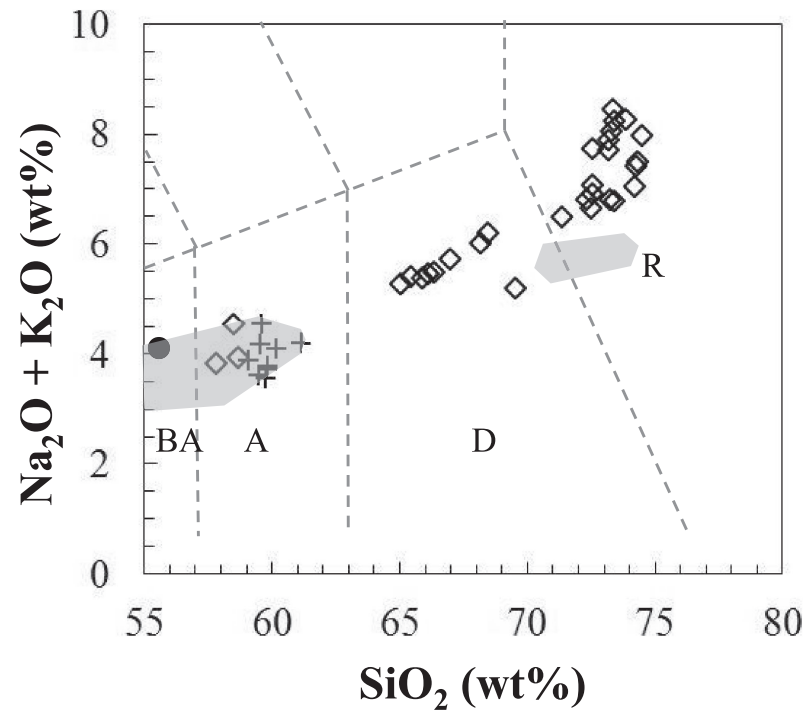

Figure 3. Compositions of plagioclase-hosted melt inclusions (diamonds) and groundmass melts (pluses). The bulk composition of the lava of Omuroyama Volcano (Suzuki, 2000) is also shown for comparison (circle). Gray-hatched areas indicate the ranges of bulk compositions of lavas in the HIMVF (Miyajima, 1990; Suzuki, 2000). BA, basaltic andesite; A, andesite; $\mathrm{D}$, dacite; R, rhyolite.

groundmass glass in these samples are shown on Figures 3 and 4, and in Table S1 (Table S1 is available online from https://doi.org/10.2465/jmps.190724). The bulk compositions of the lava of the Izu-Omuroyama Volcano (Suzuki, 2000) and other magmas in the HIMVF are also shown for comparison. $\sim 59 \%$ of the measured plagioclase-hosted MIs have rhyolitic compositions with $\mathrm{SiO}_{2}$ contents of $\sim 71-75 \mathrm{wt} \%$, although $\sim 10$ and $\sim 31 \%$ of MIs are andesitic $\left(\mathrm{SiO}_{2} \sim 58 \mathrm{wt} \%\right)$ and dacitic $\left(\mathrm{SiO}_{2} \sim 65-69 \mathrm{wt} \%\right)$, respectively. The groundmass melt has a range of $\mathrm{SiO}_{2}$ contents $(\sim 59-61 \mathrm{wt} \%)$ similar to those of the andesitic MIs. With decreasing contents of $\mathrm{SiO}_{2}$ in the MIs, the concentrations of $\mathrm{TiO}_{2}(0.03-1.5 \mathrm{wt} \%), \mathrm{FeO}^{*}(0.5-10 \mathrm{wt} \%)$, $\mathrm{MnO}(0.02-0.2 \mathrm{wt} \%), \mathrm{MgO}(0.07-5.2 \mathrm{wt} \%)$, and $\mathrm{CaO}$ (1.3-8.3 wt\%) increase while those of $\mathrm{Na}_{2} \mathrm{O}(5.4-2.8$ wt $\%)$ and $\mathrm{K}_{2} \mathrm{O}(3.3-1 \mathrm{wt} \%)$ decrease towards the typical compositions of the groundmass melt (Fig. 4). The $\mathrm{Al}_{2} \mathrm{O}_{3}$ contents are almost constant around $\sim 14.5 \mathrm{wt} \%$ for andesitic and dacitic MIs. For rhyolitic MIs, $\mathrm{Al}_{2} \mathrm{O}_{3}$ content increases with decreasing $\mathrm{SiO}_{2}$ content and the chemical variation is well explained by plagioclase control (Fig. 4). The rhyolitic MI with the lowest $\mathrm{Al}_{2} \mathrm{O}_{3}$ content (\#241plg-3 in Table $\mathrm{S} 1$ ) has $\mathrm{Al}_{2} \mathrm{O}_{3}$ content similar to those of andesitic-dacitic MIs and other silicic magmas in the HIMVF. Therefore, we think that the $\mathrm{Al}_{2} \mathrm{O}_{3}$ content variation of the rhyolitic MIs are attributed to dissolution of host plagioclase and the rhyolitic MI with the lowest $\mathrm{Al}_{2} \mathrm{O}_{3}$ content represents the original melt composition at the timing of entrapment; hereafter, we call the rhyolitic melt as 'the unmodified rhyolitic (UR) melt'.

The An\# of the host plagioclase crystals are $\sim 44.7 \pm$ $4.2(1 \sigma)$ for the rhyolitic and dacitic MIs, and $~ 73.0-76.5$ for the andesitic MIs (Fig. 5 and Table S2) (Table S2 is available online from $\mathrm{https} / / / \mathrm{doi} . o r g / 10.2465 / \mathrm{jmps}$. 190724). The andesitic MI-hosting plagioclase crystals have An\# similar to those of plagioclase microphenocrysts in the groundmass and the rims of the phenocrysts (Fig. 6). In addition, the $\mathrm{FeO}^{*}$ and $\mathrm{K}_{2} \mathrm{O}$ contents of the host plagioclase crystals are $\sim 0.2-0.3 \mathrm{wt} \%$ and $\sim 0.25-$ $0.45 \mathrm{wt} \%$, respectively, for the rhyolitic and dacitic MIs, and $\sim 0.65 \mathrm{wt} \%$ and $\sim 0.07 \mathrm{wt} \%$, respectively, for the andesitic MIs. These $\mathrm{FeO}^{*}$ and $\mathrm{K}_{2} \mathrm{O}$ contents are also similar to those of the plagioclase microphenocrysts and the rims of the phenocrysts (Fig. 6). The compositional similarities between the andesitic MIs and the groundmass melt, and also between the host plagioclase crystals of the andesitic MIs and the phenocryst rims and plagioclase microphenocrysts, indicate that the andesitic MI-hosting plagioclase crystallized simultaneously with the plagioclase microphenocrysts in the groundmass melt. The rims of the plagioclase phenocrysts also crystallized at that time. On the other hand, the lower $\mathrm{FeO}^{*}$ and higher $\mathrm{K}_{2} \mathrm{O}$ contents of the plagioclase crystals that host the dacitic-rhyolitic MIs suggest that those plagioclase crystals were derived from a Fe-poor, K-rich silicic melt. The $\mathrm{An} \#-\mathrm{FeO}^{*}-\mathrm{K}_{2} \mathrm{O}$ compositional gaps between the dacitic-rhyolitic and the andesitic MI-hosting plagioclase crystals indicate that the dacitic-rhyolitic MIs and the andesitic MIs were formed under temporally and/or spatially separated conditions.

We used the plagioclase-melt partition coefficients (D) of $\mathrm{FeO}^{*}$ and $\mathrm{K}_{2} \mathrm{O}$ (Bindeman et al., 1998) to estimate the compositions of plagioclase in equilibrium with the rhyolitic MIs ( 0.55-1 $\mathrm{wt}^{\circ} \% \mathrm{FeO}^{*}$ and $\sim 2.2-3.3 \mathrm{wt} \%$ $\mathrm{K}_{2} \mathrm{O}$ ). The partition coefficients are described as follows:

$$
\mathrm{R} T \ln D=\mathrm{a}(\mathrm{An} \# / 100)+\mathrm{b},
$$

where $\mathrm{R}$ is the gas constant, $T$ is absolute temperature, a is $-35.2 \mathrm{~kJ}$ for $\mathrm{Fe}$ and $-25.5 \mathrm{~kJ}$ for $\mathrm{K}$, and $\mathrm{b}$ is $4.5 \mathrm{~kJ}$ for $\mathrm{Fe}$ and $-10.2 \mathrm{~kJ}$ for $\mathrm{K}$. Because the plagioclase-melt compositional relationship depends on temperature and the $\mathrm{H}_{2} \mathrm{O}$ content of the melt (e.g., Putirka, 2008), it is difficult to determine the temperature condition of the host plagioclase-MI system without a constraint on the melt $\mathrm{H}_{2} \mathrm{O}$ content. We assumed, therefore, that the temperature of the rhyolitic MIs was $790-850{ }^{\circ} \mathrm{C}$, which is the pre-eruptive temperature range of silicic magmas in the HIMVF, as estimated by Suzuki (2000). This temperature range is consistent with those of natural rhyolitic 

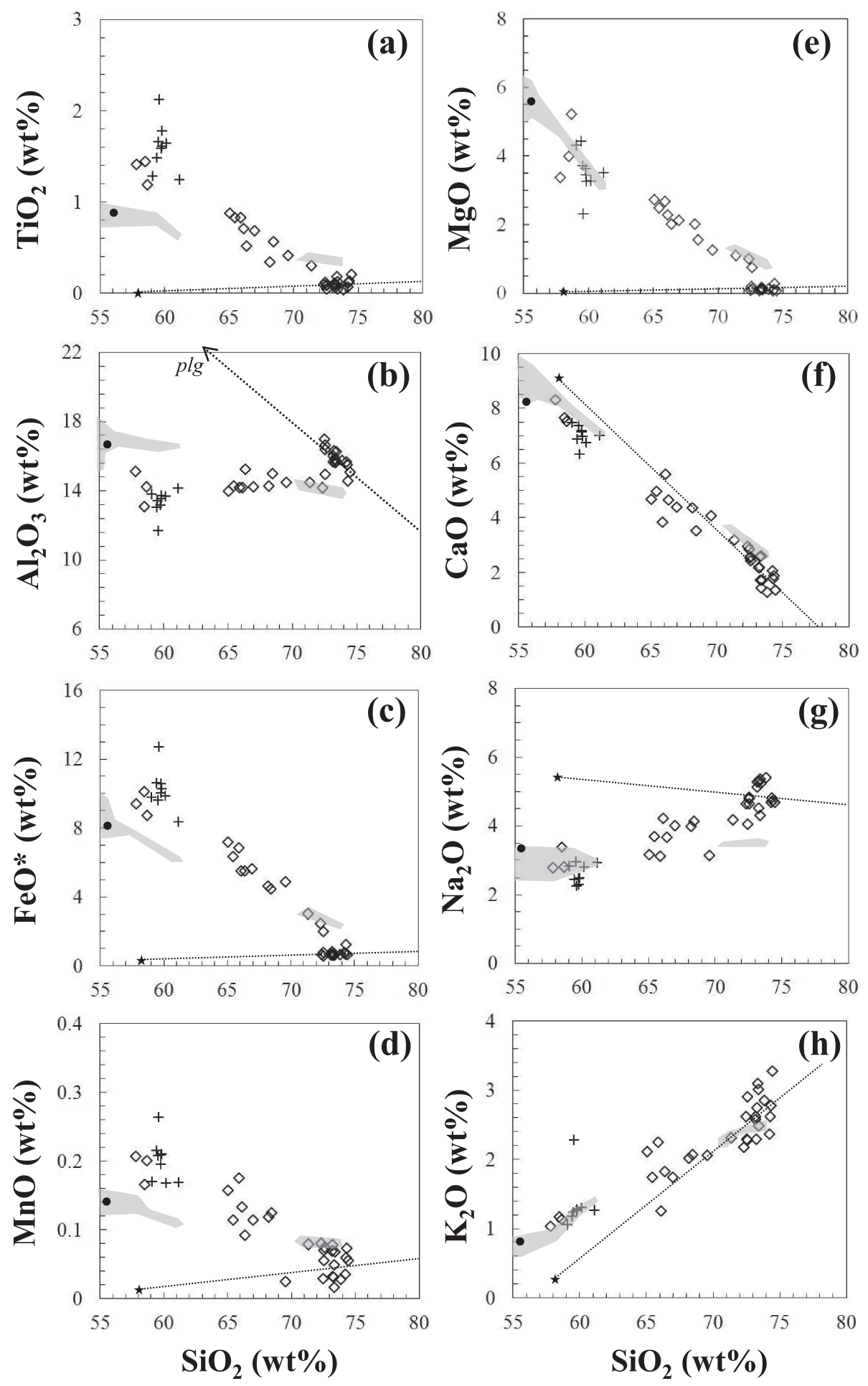

Figure 4. Major element compositions of the plagioclase-hosted MIs (diamonds) and the groundmass glass in the glassy groundmass (crosses). Gray-hatched areas indicate the ranges of bulk compositions of lavas in the HIMVF (Miyajima, 1990; Suzuki, 2000). Solid circles are the bulk composition of the Omuroyama lava (Suzuki, 2000), stars are the average compositions of silicic MI-hosting plagioclase and the dotted lines are plagioclase-control lines. $\mathrm{FeO}^{*}$, total iron as ferrous.

melts worldwide, according to the compilation of Takeuchi (2011). The calculated $\mathrm{FeO}^{*}$ and $\mathrm{K}_{2} \mathrm{O}$ contents in plagioclase in equilibrium with the rhyolitic MIs are shown in Figure 6. The results are consistent with the compositions of the dacitic-rhyolitic MI-hosting plagioclase crystals, indicating that the host plagioclase crystals were in equilibrium with the rhyolitic MIs. The dacitic MIs have $\mathrm{FeO}^{*}$ contents of $\sim 4-8 \mathrm{wt} \%$ (Fig. 4), which are too high for their host plagioclase crystals to be in equilibrium; consequently, we suggest that the dacitic MIs were in disequilibrium with their host plagioclase crystals. For all major elements, the andesitic-dacitic MIs, the 


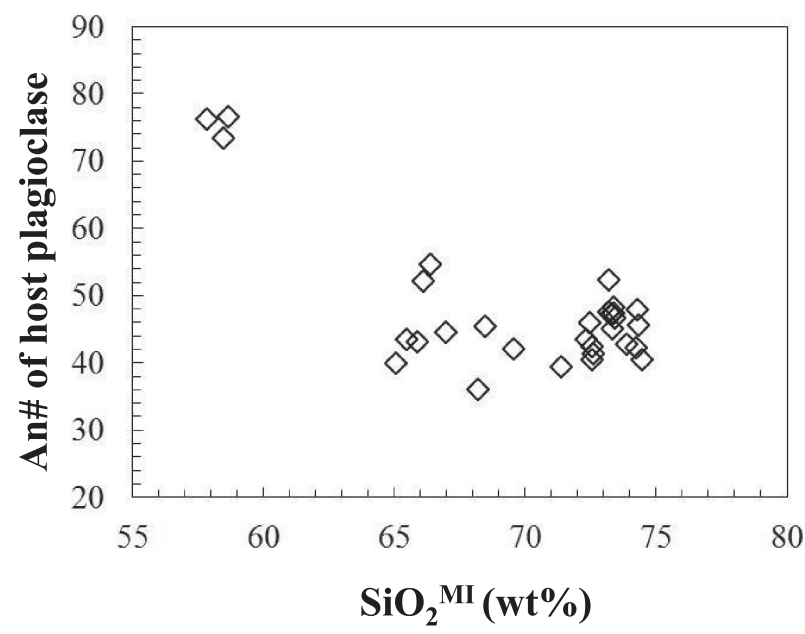

Figure 5. Relationships between the $\mathrm{SiO}_{2}$ contents of the MIs and the An\# of their host plagioclase crystals.
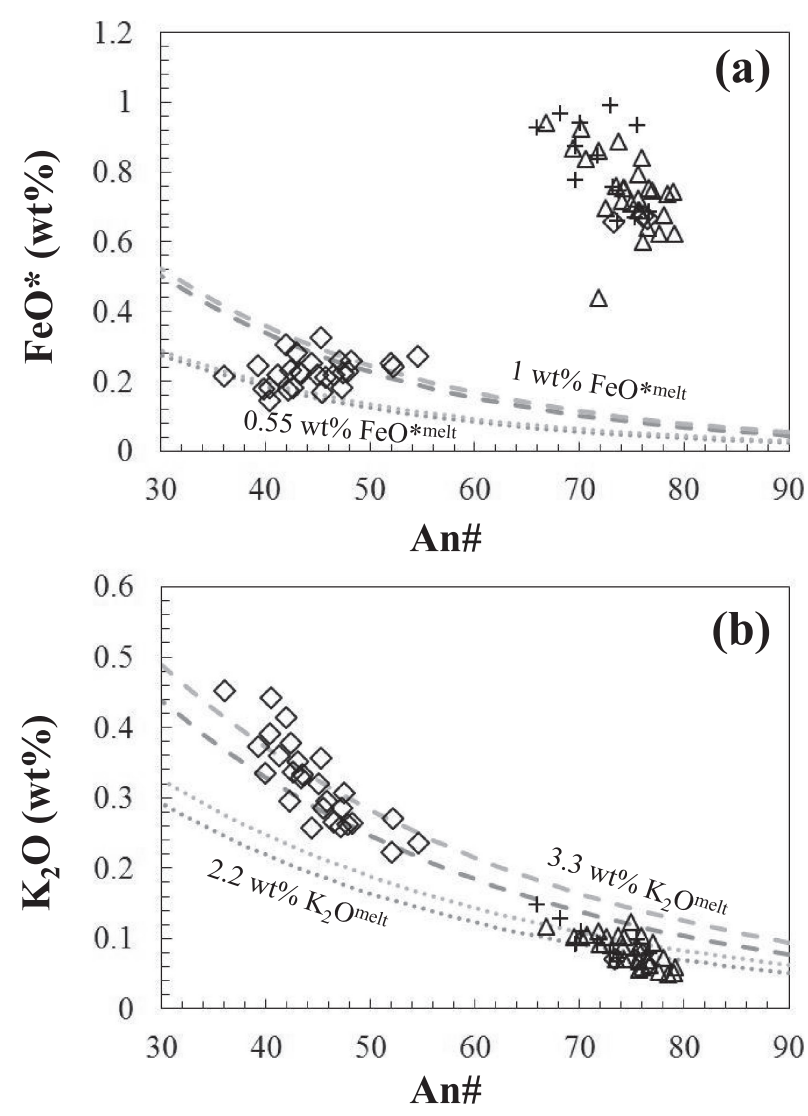

Figure 6. (a) $\mathrm{FeO}^{*}$ and (b) $\mathrm{K}_{2} \mathrm{O}$ contents plotted against the An\# of MI-hosting plagioclase crystals (diamonds), the rims of plagioclase phenocrysts (triangles), and plagioclase microphenocrysts (pluses). The dotted and dashed curves indicate the compositions of plagioclase in equilibrium with melts with $\mathrm{FeO}^{*}=$ $0.55 \mathrm{wt} \%$ and $\mathrm{K}_{2} \mathrm{O}=2.2 \mathrm{wt} \%$, or $\mathrm{FeO}^{*}=1 \mathrm{wt} \%$ and $\mathrm{K}_{2} \mathrm{O}=3.3$ $\mathrm{wt} \%$, respectively. The colors of the curves indicate temperatures of $790{ }^{\circ} \mathrm{C}$ (dark gray) and $850{ }^{\circ} \mathrm{C}$ (light gray).
UR melt and the groundmass melts show linear relationships (Fig. 4), and the dacitic MIs plot between the UR melt and the groundmass melts. These relationships suggest that the dacitic MIs were the products of mixing between the UR melt and the groundmass melts immediately before the eruption. Some of the rhyolitic MIs probably became connected to the groundmass melt after their entrainment as a result of the partial melting/fracturing of their host plagioclase phenocrysts (Fig. 2). In fact, similar plagioclase textures were represented by the partial dissolution experiments of Nakamura and Shimakita (1998). The plagioclase-controlled compositional variation of the rhyolitic MIs (Fig. 4) was also formed by heating at that time; these MIs were not connected to the groundmass melt and reacted only with their host plagioclase. Our data and observations indicate that the rhyolitic melt was not derived from the groundmass melt, and we propose, therefore, that a reservoir of plagioclase-bearing rhyolitic melt existed beneath the present Omuroyama Volcano approximately 4000 years ago, which predates the first rhyolitic eruption in the HIMVF by $\sim 800$ years. We estimated the $\mathrm{H}_{2} \mathrm{O}$ content of the UR melt by using the plagioclase liquidus and the plagioclase-melt An-partition thermohygrometers of Putirka (2008). We used the compositions of the UR melt (\#2-41plg-3 in Table S1) and the average composition of rhyolitic MI-hosting plagioclase crystals (An\# $\sim 44.7 \pm 4.2$ ). We assumed the temperature was $790-850{ }^{\circ} \mathrm{C}$, as mentioned above. Assuming the estimated error of $\pm 1 \mathrm{wt} \% \mathrm{H}_{2} \mathrm{O}$ for the thermohygrometers, the $\mathrm{H}_{2} \mathrm{O}$ content of the UR melt was estimated to be in the range $\sim 4.4-10.2 \mathrm{wt} \%$ (Fig. 7). Comparing this with the $\mathrm{H}_{2} \mathrm{O}$ solubility curve for rhyolitic melts calculated with the VolatileCalc program (Newman and Lowerstern, 2002), we estimated the $\mathrm{H}_{2} \mathrm{O}$ saturation pressure to be 124-407 MPa. Suzuki (2000) estimated the $\mathrm{H}_{2} \mathrm{O}$ saturation pressures for silicic magmas erupted in the volcanic field to be $\sim 200 \mathrm{MPa}$, which is consistent with the present results for the rhyolitic MIs. The estimated $\mathrm{H}_{2} \mathrm{O}$ saturation pressures of 124 and $407 \mathrm{MPa}$ correspond to lithostatic depths of $\sim 4.5-5.1$ and $\sim 14.8-16.6$ $\mathrm{km}$, assuming a crustal density of $2500-2800 \mathrm{~kg} / \mathrm{m}^{3}$. The depth of the inhibited silicic reservoir was therefore greater than $4.5 \mathrm{~km}$.

The groundmass melts have andesitic compositions similar to those of the andesitic MIs and were coexisted with olivine and plagioclase microphenocrysts. Therefore, we estimate the temperature and $\mathrm{H}_{2} \mathrm{O}$ content conditions of the groundmass melt by combining the plagioclase liquidus and the plagioclase-melt An-partition thermohygrometers and the pressure-independent olivine liquidus thermometer of Putirka (2008). We used the average compositions of the groundmass melt (Table 


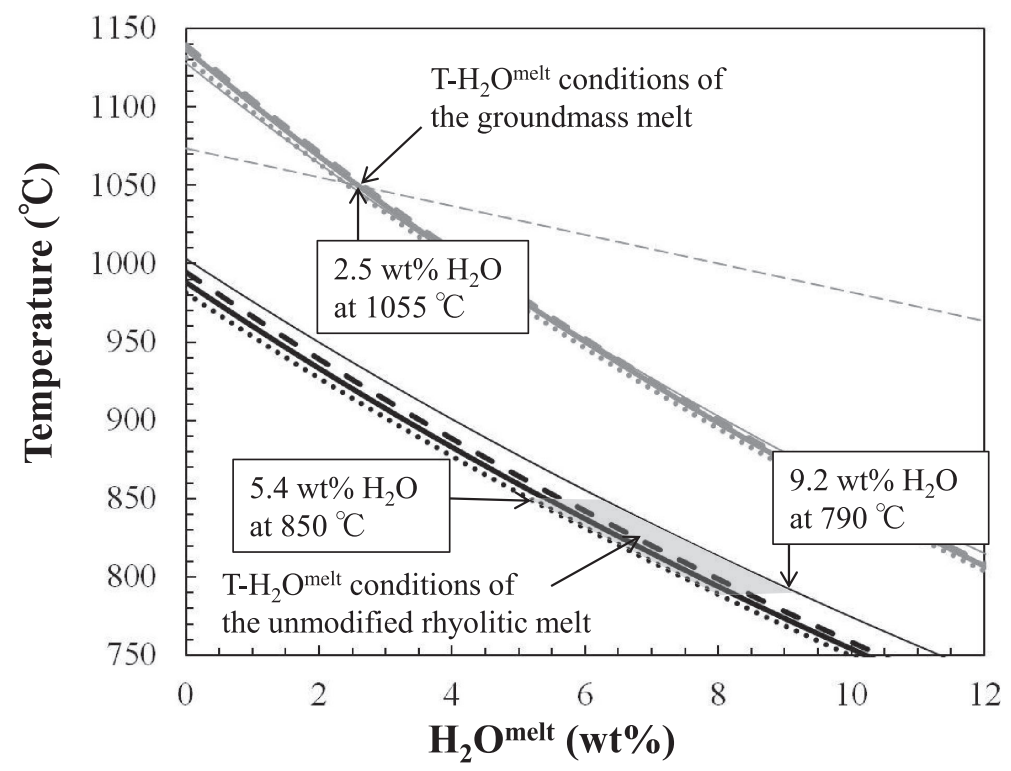

Figure 7. The estimated temperature- $\mathrm{H}_{2} \mathrm{O}$ content $\left(\mathrm{H}_{2} \mathrm{O}^{\text {melt }}\right)$ conditions for the UR rhyolitic melt and the groundmass melt. The black and gray curves indicate the calculated relations for the UR melt and the groundmass melt, respectively. Thick curves indicate the results calculated by the plagioclasemelt An-partitioning thermohygrometer of Putirka (2008). An\# of coexisting plagioclase used are 44.7 (solid), 48.9 (broken), 40.5 (dotted) for the UR melt, and An\# 72 (solid), 75 (broken), 66 (dotted) for the groundmass melt, respectively. Thin solid and broken curves are the results calculated by the plagioclase-liquidus thermohygrometer and the olivine liquidus thermometer of Putirka (2008), respectively. The gray hatched area indicates the temperature$\mathrm{H}_{2} \mathrm{O}^{\text {melt }}$ condition of the UR melt.
S1) and the compositions of plagioclase microphenocrysts with An\# of $\sim 66-75$ with the average of $\sim 72$ for the estimation (Table S2). The estimated temperature and $\mathrm{H}_{2} \mathrm{O}$ content conditions are $\sim 1055{ }^{\circ} \mathrm{C}$ and $2.5 \mathrm{wt} \%$, respectively (Fig. 7). Using the $\mathrm{H}_{2} \mathrm{O}$ solubility curve for basaltic and rhyolitic melts calculated by VolatileCalc program, the $\mathrm{H}_{2} \mathrm{O}$-saturation pressure is calculated to be $\sim 75$ $\pm 52 \mathrm{MPa}$, which corresponds to the lithostatic depth of $\sim 3.0 \pm 2.2 \mathrm{~km}$ assuming a crustal density of 2500-2800 $\mathrm{kg} / \mathrm{m}^{3}$ and the estimated error of melt $\mathrm{H}_{2} \mathrm{O}$ content of \pm 1 $\mathrm{wt} \%$. The estimated lithostatic depth for the groundmass melt is shallower than that of the UR melt. The result is consistent with the observation that plagioclase phenocryst has low-An\# core surrounded by high-An\# rim and the composition of the rim part is the same as those of plagioclase microphenocrysts. Kawamoto (1996) performed the crystallization experiments of the hydrous basaltic magma from the HIMVF at 0.5 and $1 \mathrm{GPa}$. We compared the composition and the estimated $\mathrm{T}-\mathrm{H}_{2} \mathrm{O}$ conditions of the groundmass melt with those of the experimental melts. At similar $\mathrm{SiO}_{2}$ content, the experimental melts at $0.5 \mathrm{GPa}$ have higher $\mathrm{Al}_{2} \mathrm{O}_{3}(\sim 17-18 \mathrm{wt} \%)$, lower FeO* ( 4.5-6.5 wt \%) and higher $\mathrm{H}_{2} \mathrm{O}$ contents $(3-5 \mathrm{wt} \%$ determined by the difference of electron microprobe total from 100) compared to the groundmass melt. The temperature conditions are similar. The compositional differences are attributed to the depression of plagioclase crystallization under high $\mathrm{H}_{2} \mathrm{O}$ contents. Therefore, the estimated $\mathrm{T}-\mathrm{H}_{2} \mathrm{O}$ conditions of the groundmass melt is consistent with the results of Kawamoto (1996).

Our new data and observations lead us to propose the following process for the Izu-Omuroyama eruption. Before $\sim 4000$ years ago, a reservoir of plagioclase-bear- ing rhyolitic melt existed at a depth greater than $4.5 \mathrm{~km}$ beneath the present Omuroyama Volcano. Around 4000 years ago, an olivine-bearing mafic magma that was derived from a greater depth has intruded into the silicic reservoir where it mixed with the plagioclase-bearing rhyolitic melt to form an olivine-plagioclase-bearing basaltic andesite magma. This magma then ascended to shallower depths of $\sim 3.0 \mathrm{~km}$, crystallizing olivine and plagioclase microphenocrysts before it was erupted.

We roughly estimate the mixing ratio of the rhyolitic end-member melt (represented by the UR melt; $\mathrm{SiO}_{2}$ $\sim 74.4 \mathrm{wt} \%$ ) and the mafic end-member melt based on mass balance consideration of $\mathrm{SiO}_{2}$ contents, assuming that $\mathrm{SiO}_{2}$ content of the mixed melt is the same as that of the bulk $\mathrm{SiO}_{2}$ content of the Omuroyama magma ( $55.4 \mathrm{wt} \%$; Suzuki, 2000). This assumption is valid because the magma is phenocryst-poor (0.4-3.4 and 1.1-5.7 vol\% for olivine and plagioclase, respectively). $\mathrm{SiO}_{2}$ content of the mafic end-member melt is assumed to be $49-53 \mathrm{wt} \%$ based on the general range of the mafic magmas in the HIMVF (Miyajima, 1990; Suzuki, 2000). The mixing ratio of the rhyolitic melt, $X_{\text {rhy }}$, is calculated to be 11.2 and $25.2 \mathrm{wt} \%$ for the assumed $\mathrm{SiO}_{2}$ content of the mafic end-member melt of 53 and $49 \mathrm{wt} \%$, respectively. In addition, we estimate the plagioclase content in the plagioclase-bearing rhyolitic melt assuming all plagioclase phenocrysts were derived from the magma and the densities of plagioclase and melt are the same. For such case, plagioclase content in the silicic magma, $\Phi_{\text {plg }}$, is calculated as follows:

$$
\Phi_{\mathrm{plg}}=V_{\mathrm{plg}} /\left(V_{\mathrm{plg}}+V_{\mathrm{mlt}} \times X_{\text {rhy }}\right),
$$


where $V_{\mathrm{plg}}$ and $V_{\mathrm{mlt}}$ are the volume fractions of plagioclase phenocryst and the mixed melt (i.e., groundmass) in the Omuroyama magma. The estimated $\Phi_{\mathrm{plg}}$ is up to 35.8 vol\% with $0.4-3.4$ vol $\%$ olivine, $1.1-5.7$ vol $\%$ plagioclase, and $49-53 \mathrm{wt} \% \mathrm{SiO}_{2}$ of the mafic end-member melt. The result suggests that the reservoir of plagioclase-bearing rhyolitic melt was fluidal, not mushy, implying that an eruptible rhyolitic melt existed beneath Omuroyama. Assuming the density of basaltic andesite to be $2700 \mathrm{~kg} / \mathrm{m}^{3}$, the erupted volume of the Omuroyama magma is $\sim 0.17 \mathrm{~km}^{3}$. Furthermore, the volume fraction of the silicic end-member magma (i.e., plagioclase phenocrysts + the rhyolitic melt) contributed to form the Omuroyama magma is $12.3-30.9 \mathrm{vol} \%$. Therefore, $>0.021-$ $0.052 \mathrm{~km}^{3}$ of plagioclase-bearing rhyolitic melt existed immediately before the Omuroyama eruption.

In the HIMVF, the first rhyolitic eruption occurred $\sim 3200$ years ago at the Kawagodaira Volcano (Shimada, 2000 ), which is located $\sim 10 \mathrm{~km} \mathrm{SW}$ of the Omuroyama Volcano. The rhyolitic glass of the Kawagodaira Volcano is more silicic $\left(\mathrm{SiO}_{2} \sim 78 \mathrm{wt} \%\right)$ than that of the Omuroyama Volcano, and amphibole-plagioclase crystal clots are often found (Suwa et al., 2018). Amphiboles are also found in the volcanic products of other silicic volcanoes that erupted in the HIMVF after the Kawagodaira eruption (Miyajima, 1990). Previous researchers have discussed the petrogenesis of silicic magmas in the HIMVF, and Suzuki (2000), for example, suggested that the silicic magmas were formed by the partial melting of a felsic crustal rock with residual phases of plagioclase and amphibole. In addition, the experimental results of Kawamoto (1996) show that the rhyolitic melts with compositions similar to the UR melt coexist with amphibole, pyroxene, magnetite and plagioclase. On the other hand, no amphibole is found in the Omuroyama magma. One possible hypothesis for the absence of amphibole is that amphibole was fractionated from the plagioclase-bearing rhyolitic melt. Our estimation of crystal content suggests that the plagioclase-bearing rhyolitic melt was fluidal. Under the condition, amphibole, as well as pyroxene and $\mathrm{Fe}-\mathrm{Ti}$ oxides, were gravitationally fractionated due to their large densities. In fact, pyroxene and Fe-Ti oxide phenocrysts are also absent. On the other hand, plagioclase could remain in the convecting rhyolitic melt due to small density contrast between plagioclase and rhyolitic melt. To examine this hypothesis and clarify the origin of the silicic magma, we require further geochemical studies of the plagioclase-hosted rhyolitic MIs as well as studies of the partially molten crustal xenoliths reported by Hamuro (1985). Koyama and Umino (1991) suggested that repetitively supplied mafic magmas induce melting of rocks in the upper crust to form silicic magmas. Miyajima
(1990) pointed out that andesitic monogenetic volcanoes are clustered along the eastern side of the HIMVF (Fig. 1). We infer, therefore, that inhibited silicic reservoirs may also exist beneath these andesitic volcanoes. This hypothesis can be tested by further analytical studies of the plagioclase-hosted MIs in these volcanoes.

Our results demonstrate the potential usefulness of plagioclase-hosted MIs as an indicator of an inhibited silicic melt beneath mafic volcanoes and volcanic fields. Identifying the presence of silicic magmas is fundamental in the assessment of volcanic hazards. We recommend, therefore, that the analysis of plagioclase-hosted MIs from mafic volcanoes and volcanic fields be used as an essential tool when identifying inhibited silicic magmas for the purposes of hazard migration.

\section{CONCLUDING REMARKS}

We presented the results of our textural and chemical analyses of MIs and their host plagioclase crystals in the scoria from Izu-Omuroyama Volcano, Japan. Our results suggest that an inhibited reservoir of plagioclase-bearing rhyolitic melt existed at depth greater than $4.5 \mathrm{~km}$ beneath this monogenetic volcano at the time of its eruption at $\sim 4$ $\mathrm{ka}, \sim 800$ years before the first rhyolitic eruption in this volcanic field. The results demonstrate the potential usefulness of plagioclase-hosted MIs as an indicator of an inhibited silicic magma reservoir beneath mafic volcanoes and volcanic field.

\section{ACKNOWLEDGMENTS}

We are grateful to the editors Prof. Nakamura, M. and Prof. Satish-Kumar, M. and the reviewer, Dr. Hamada, M., who provided thoughtful comments that have improved the manuscript to an enormous degree. This research was supported by JSPS KAKENHI Grant Number JP16K05606 and JP19K04014, the Earthquake Research Institute cooperative program, the University of Tokyo, Japan (2018-G-02, 2019-G-01), and the Integrated Program for Next Generation Research and Human Resource Development, MEXT, Japan.

\section{SUPPLEMENTARY MATERIALS}

Supplementary Tables S1 and S2 are available online from https://doi.org/10.2465/jmps.190724.

\section{REFERENCES}

Bindeman, I.N., Davis, A.M. and Drake, M.J. (1998) Ion microprobe study of plagioclase-basalt partition experiments at nat- 
ural concentration levels of trace elements. Geochimica et Cosmochimica Acta, 62, 1175-1193.

Fujii, T. (2007) Magmatology of Fuji volcano. In Fuji Volcano (Volcanological Society of Japan Ed.). Yamanashi Institute of Environmental Science, 233-244 (in Japanese with English abstract).

Hamuro, K. (1985) Petrology of the Higashi-Izu monogenetic volcano group. Bulletin of the Earthquake Research Institute, 60, $335-400$.

Hasegawa, A., Nakajima, J., Uchida, N., Okada, T., et al. (2009) Plate subduction, and generation of earthquakes and magmas in Japan as inferred from seismic observations: An overview. Gondwana Research, 16, 370-400.

Houghton, B.H., Wilson, C.J.N., Del Carlo, P., Coltelli, M., et al. (2004) The influence of conduit process on changes in style of basaltic Plinian eruptions: Tarawara 1886 and Etna 122 BC. Journal of Volcanology and Geothermal Research, 137, 1-14.

Kaneko, T., Yasuda, A., Fujii, T. and Yoshimoto, M. (2010) Crypto-magma chambers beneath Mt. Fuji. Journal of Volcanology and Geothermal Research, 193, 161-170.

Kawamoto, T. (1996) Experimental constraints on differentiation and $\mathrm{H}_{2} \mathrm{O}$ abundance of calc-alkaline magmas. Earth and Planetary Science Letters, 144, 577-589.

Koyama, M., Hayakawa, Y. and Arai, F. (1995) Eruption history of the Higashi-Izu monogenetic volcano field 2: Mainly on volcanoes older than 32,000 years ago. Kazan, 40, 191-209 (in Japanese with English abstract).

Koyama, M. and Umino, S. (1991) Why does the Higashi-Izu monogenetic volcano group exist in the Izu Peninsula ?: Relationships between late Quaternary volcanism and tectonics in the northern tip of the Izu-Bonin arc. Journal of Physics of the Earth, 39, 391-420.

Koyano, Y., Hayakawa, Y. and Machida, Y. (1996) The eruption of Omuroyama in the Higashi Izu monogenetic volcano field. Journal of Geography, 105, 475-484 (in Japanese with English abstract).

Miyaji, N. (2007) Eruption history, eruption rate and scale of eruptions for the Fuji Volcano during the last 11,000 years. In Fuji Volcano (Volcanological Society of Japan Ed.). Yamanashi Institute of Environmental Science, 79-95 (in Japanese with English abstract)

Miyaji, N., Kan'no, A., Kanamaru, T. and Mannen, K. (2011) High-resolution reconstruction of the Hoei eruption (AD 1707) of Fuji volcano, Japan. Journal of Volcanology and Geothermal Research, 207, 113-129.

Miyajima, H. (1990) Petrology of Higashi-Izu monogenetic volcano group - Implication of xenocrysts, time and spatial variation of ejecta-. Journal of Mineralogy, Petrology and Economic Geology, 85, 315-336 (in Japanese with English abstract).

Nagasaki, S., Ishibashi, H., Suwa, Y., Yasuda, A., et al. (2017)
Magma reservoir conditions beneath Tsurumi volcano, SW Japan: Evidence from amphibole thermobarometry and seismicity. Lithos, 278-281, 153-165.

Nakamura, M. and Shimakita, S. (1998) Dissolution origin and syn-entrapment compositional change of melt inclusion in plagioclase. Earth and Planetary Science Letters, 161, 119-153.

Newman, S. and Lowerstern, J.B. (2002) VolatileCalc: a silicate melt $-\mathrm{H}_{2} \mathrm{O}-\mathrm{CO}_{2}$ solution model written in Visual Basic for excel. Computers \& Geosciences, 28, 597-604.

Putirka, K.D. (2008) Thermometers and barometers for volcanic systems. In Minerals, inclusions and volcanic processes $(\mathrm{Pu}-$ tirka, K.D. and Tepley, F.J III Eds.). Reviews in Mineralogy and Geochemistry, Mineralogical Society of America and Feochemical Society, 69, 61-120.

Sable, J.E., Houghton, B.F., Del Carlo, P. and Coltelli, M. (2006) Changing conditions of magma ascent and fragmentation during the Etna $122 \mathrm{BC}$ basaltic Plinian eruption: Evidence from clast microstructures. Journal of Volcanology and Geothermal Research, 158, 333-354.

Saito, T., Takahashi, S. and Wada, H. (2003) ${ }^{14} \mathrm{C}$ ages of Omuroyama volcano, Izu Peninsula. Kazan, 48, 215-219 (in Japanese with English abstract).

Shimada, S. (2000) Eruption of the Amagi-Kawagodaira volcano and paleo-environments in the late and latest Jomon periods around the Izu peninsula. The Quaternary Research, 39, 151164 (in Japanese with English abstract).

Suzuki, Y. (2000) Petrogenesis of felsic magma in Higashi-Izu monogenetic volcano group. Kazan, 45, 149-171 (in Japanese with English abstract).

Suwa, Y., Ishibashi, H., Hokanishi, N. and Yasuda, A. (2018) Preeruptive magmatic process of silicic monogenetic volcano inferred from amphibole phenocrysts: A case study of IzuKawagodaira volcano. Abstract of Japan Geoscience Union Meeting 2018, SVC39-P04.

Takahashi, M., Kominami, M., Nemoto, Y., Hasegawa, Y., et al. (2003) Whole-rock chemistry for eruptive products of Fuji volcano, Central Japan: Summary of analytical data of 847 samples. Proceedings of the Institute of Natural Sciences, Nihon University, 38, 117-166.

Takeuchi, S. (2011) Preeruptive magma viscosity: An important measure of magma eruptibility. Journal of Geophysical Research, 116, B10201, doi:10.1029/2011JB008243.

Yamamoto, T., Soya, T., Suto, S., Uto, K., et al. (1991) The 1989 submarine eruption off eastern Izu Peninsula, Japan: ejecta and eruption mechanisms. Bulletin of Volcanology, 53, 301-308.

Manuscript received July 24, 2019

Manuscript accepted March 23, 2020

Published online June 26, 2020

Manuscript handled by Michihiko Nakamura and M. Satish-Kumar 